UDC 692.415

DOI https://doi.org/10.32782/2664-0406.2020.37.9

\title{
Prybytko I.O.
}

$\mathrm{PhD}$ in Technical Sciences,

Associate Professor at the Department of Welding Technologies and Construction,

National University "Chernihiv Polytechnic", Chernihiv

\section{Bolotov M.H.}

$\mathrm{PhD}$ in Technical Sciences,

Associate Professor at the Department of Welding Technologies and Construction,

National University "Chernihiv Polytechnic”, Chernihiv

\section{Rudenko M.M.}

Senior Lecturer at the Department of Welding Technologies and Construction, National University "Chernihiv Polytechnic", Chernihiv

\section{STUDY OF GEOMETRICAL PARAMETERS INFLUENCE OF PROFILED DECKING ON BEARING CAPACITY OF THE ROOF}

\begin{abstract}
Nowadays, roofing is one of the most important features of our home. It controls temperatures, adds architectural appeal and protects from different kind of natural disasters. Depending on what roof type you choose for your structure, you may be using roof tiles, ridge caps, metal roofing sheets, underlayment and roof insulation. The main advantage of the metal roof panels and corrugated roofing have a much longer life. They are possess of good fire-resistance abilities and reflects the heat. Moreover, metal roofing sheets are maintained quite quickly and easily. Nevertheless, the metal roofing has a few cons mainly related with the massive weight of such construction and the huge metal consumption as well, let alone of their cost.

In this case, the article considers of the current problem, related with the searching of ways of the metal consumption decreasing in the processes of roofing manufacturing by means of modeling of the different overlapping construction of industrial buildings at the accounting of rigidity of a profiled flooring in the modern mathematical packages: APM WinMachine, SolidWorks, and ANSYS.

The main results of this study can be summarized, as follows: the profiled flooring increases rigidity of a roof, reducing a trusses deflection (by 20-30\%); the profiled flooring changes a picture of stresses distribution in the trusses elements dramatically. By taking into account of profiled flooring rigidity there is an opportunity to reduce metal consumption of overlapping designs of industrial buildings. Studies need to be conducted for each case of profiled decking (depending on the parameters roof - type of trusses, step of trusses, span values etc.). The calculation of roofing structures should be considering building carcass as a whole rather than the individual trusses.
\end{abstract}

Key words: metal construction, overlapping, profiled flooring, truss, metal consumption.

Introduction. Roofing is one of the most important structural elements of buildings as industrial and civil use. The main purpose of the roof is to protect of the building from precipitation as rain or snow, as well as the heat loss in winter and overheating in summer. The series of the research related with the buildings destruction due to the natural rainfalls was conducted in [1]. Considerable distribution was gained also are not warmed, so-called "cold roofs" (shelters for equipment, some warehouse, not heated industrial buildings, hot workshops, etc.).

In a general view the building's roof is consists, directly, of the roofing (protecting) designs, the bearing elements (runs, farms) and the communications providing a spatial permanence, rigidity and stability of a roof in general and its separate elements [2;3].

The bearing elements are made of metal, wood or reinforced concrete as a rule. The wooden roofing structures are fully considered in [4]. 
In [5] the impact of the welded reinforce joints onto the bearing capacity of the concrete structures was shown. The greatest distribution was gained by metal designs, thanks to a number of advantages:

1. The high bearing ability. Metal designs can perceive considerable efforts at rather small cuts owing to the big durability of metal.

2. High reliability. Thanks to structural homogeneity of metal and its elastic properties metal designs can be counted most accurately. It allows to provide reliability of the projected construction.

3. The ease and transportability. High mechanical properties allow the metal to withstand considerable internal stresses without deformation. Cross sections of metal structures are lighter compared to other materials with the same effort.

4. Industriality. Metal designs make from ready rolling, pressed or bent profiles at the high-mechanized enterprises. Their installation is carried out by the specialized enterprises with the minimum expenses of manual skills. They have high degree of factory readiness.

Besides, metal designs are convenient in operation as can be easily strengthened at increase in loadings. They are most fully used at reconstruction and easily are under repair.

However, along with the advantages of metal structures they also have a number of drawbacks, mainly related to low corrosion and fire resistance of most metals, which significantly limit their use.

Statement of Problem. At design of metal structures service conditions, economy of metal, transportability, technological effectiveness, high-speed installation, durability, convenience of leaving during operation and esthetics have to be considered.

The basic principle of metal structures designs is achievement of three main indicators: economy of metal, increase of labor productivity at production, decrease in labor input and terms of installation, which determine the cost of design.

Actual scientific researches analysis. In spite of the fact that these indicators often at realization contradict one another (for example, the most economical on expenses metal design often happens the most labor consuming at production and installation), experience of development of metal designs confirms possibility of realization of this principle [6].
The economy of metal in metal structures is reached by realization of the following main directions: applications in the construction designs low-alloyed and high-strength steels, use of the most economic rolling and bent profiles, search and introduction in construction of modern effective constructive forms and systems (spatial, previously intense, tubular, etc.), improvement of methods of calculation and search of optimum constructive decisions with use of computer facilities.

Purpose of the research. The aim of this work is to study the possibility of reduction of metal consumption of overlapping construction of industrial buildings at the accounting of rigidity of a profiled flooring.

Results of the research. From the point of view of metal constructions design, the steel profiled sheets are most interesting material, thanks to a number of advantages: they have rather big range of standard sizes, low cost and weight, can be applied to any tilt angles of a roof. Profiles steel sheet bent with corrugations in the form of trapezes for building are applied in construction as covering, as the barrier material in the barrier constructions (wall panels, partitions, gate, etc.), industrial buildings of light metal structures operating in aggressive and slightly aggressive environments.

Profiled sheets classify on:

1. By appointment: $\mathrm{F}$ - for flooring coatings, FW - for a flooring and wall barriers, $\mathrm{W}$ - for wall barriers.

2. By material of initial workpiece:

- sheets of zinced rolled sheet by the GOST 14918 (no designation);

- sheets of rolled sheet coated with Al-Zn by TU 14-11-247-88 (designation AZ);

- sheets of rolled sheet coated with aluminum, and Al-Si coated rolled by TU 14-11-23688 (designation $\mathrm{Al}, \mathrm{Al}-\mathrm{Si}$ );

- sheets of rolled sheet with galvanized zinc coating by TU 14-1-4695-88 (designation GZC);

3 In the presence of protective and decorative paint coating; with and without paint/varnish coating by the GOST 30246 (designation of paints and varnishes is specified).

Profiled sheets shall be made multiple by $250 \mathrm{~mm}$ in length (for F and FW sheets), multiple by $300 \mathrm{~mm}$ (for FW and W sheets). The Production of any length profiled sheets and of less than 3 and more than $12 \mathrm{~m}$ for deck is permitted by the manufacturer and the customer agreement [7]. 
The profiled decking can be used by itself and as special panels profiled sheets from (for example, the layered assembling structure provides of sequential profiled sheets installation, a vapor barrier and thermal insulation).

As roofing materials used profiled sheets up to $75 \mathrm{~mm}$ inclusive as a rule (a profiled sheets without additional materials). Profiled sheets more than $75 \mathrm{~mm}$ high use for production of multilayered panels.

The one slope truss with parallel chords and a triangular grate with additional racks was chosen for our researches (fig. 1) Rectangular section of elements of trusses is considered. We have selected the minimum size of span equal to $6 \mathrm{~m}$, and trusses step of $2 \mathrm{~m}$.

The rectangular cross-section girders also were chosen. The step of girders been set at $1 \mathrm{~m}$ and $2 \mathrm{~m}$ (two cases).

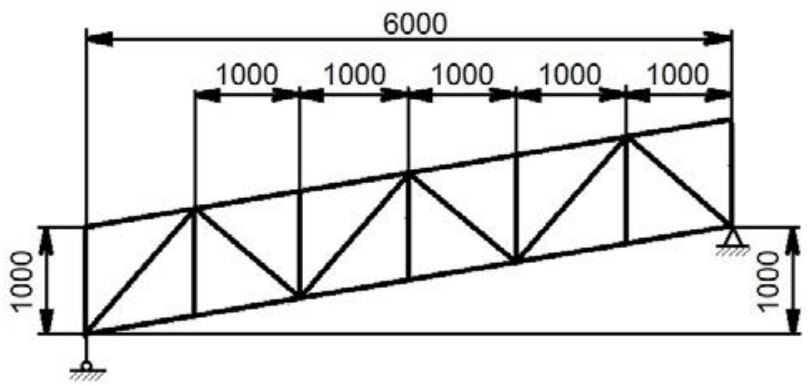

Fig. 1. The diagram of trusses structure

Today for carrying out this sort of researches possibly application of the following packages of system of the automated design: Compas 3D V12, Mathcad, ANSYS 10.0 (Workbench module), Solid Works and APM WinMachine 2008.
In this work the Compass program 3D V12 for creation of a three-dimensional carcass of a design and profiled sheets is used, and APM WinMachine 2008 the Structure 3D module, is applied to calculation by method of final elements of roofs carcass (excluding profiled flooring). As a standard the data obtained at calculation of a flat truss by a matrix method in the environment of Mathcad are used. The main calculation of a carcass with a profiled flooring is carried out in the environment of ANSYS 10.0 - Workbench. Compared to other mathematical packages the advantage of Workbench is less resource consumption.

In figure 2 the chosen scheme of a trusses which has rectangular the cross section of cores is represented.

In designation of profiled sheets leaf thickness is specified. In parentheses indicate the extreme load on girders.

The snow loads and own weight of a flooring for calculation in the environment of APM WinMachine is put twice more than is specified in table 1 as the step of runs increased twice. Similarly perform the calculation roof depending on number of profiled sheets.

One of the results of carcass calculation's in the environment of APM WinMachine shown in Figures 3 and 4, and among Workbench Figures 5 and 6.

Stress Distribution in the carcass allows us to investigate only the point, which is in the middle of the lower trusses chord. It is possible because the calculation in the Workbench environment and APM WinMachine give a similar picture of the distribution of stresses [8].

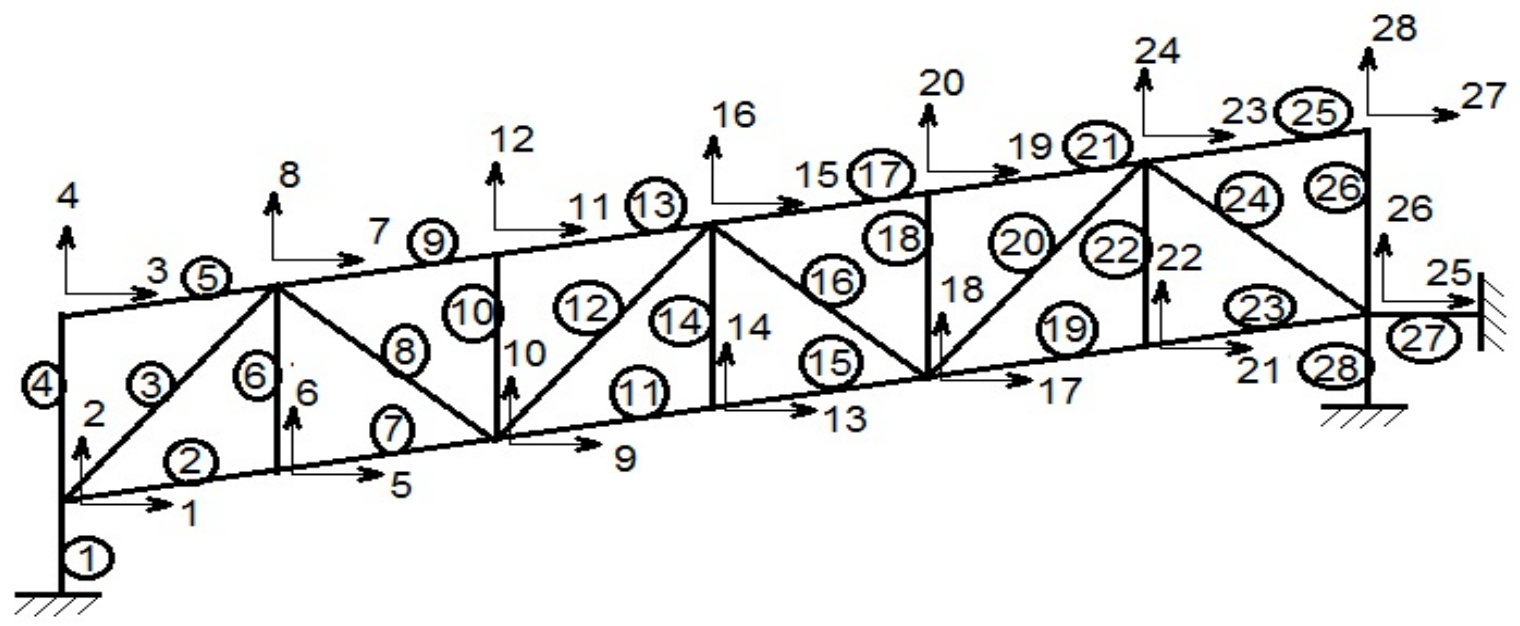

Fig. 2. Diagram of a truss: 1-28 - numbers of coordinate axes 1-28 (are led round) - numbers of rods 
Table 1. The load on the carcass

\begin{tabular}{|c|c|c|c|}
\hline \multirow{2}{*}{ Type of load } & \multirow{2}{*}{ The value of load } & \multicolumn{2}{|c|}{ The given loadings for mathematical packages } \\
\cline { 3 - 4 } & & APM WinMachine, N/mm & Workbench, Pa \\
\hline Snow & $0.0018 \mathrm{~N} / \mathrm{mmI}$ & - & - \\
\hline Weight of trusses & $240.8 \mathrm{~N}$ & 0.039456 & 1972.789 \\
\hline \multicolumn{4}{|c|}{ Densities of girders } \\
\hline 50x30x4 & $45.22 \mathrm{~N} / \mathrm{m}$ & 0.04522 & 1507.2 \\
\hline $60 \times 40 \times 5,5$ & $76.85 \mathrm{~N} / \mathrm{m}$ & 0.07685 & 1921.287 \\
\hline \multicolumn{5}{|c|}{ Specific weight of a profiled flooring + snow load } \\
\hline FW $35-0.7$ & $0.001874 \mathrm{~N} / \mathrm{mmI}$ & $1.89984(0.94992)$ & 2758.87 \\
\hline FW $44-0.7$ & $0.001883 \mathrm{~N} / \mathrm{mmI}$ & $1.90897(0.95448)$ & 2216.56 \\
\hline F $57-0.6$ & $0.001875 \mathrm{~N} / \mathrm{mmI}$ & $1.90086(0.95043)$ & 2659.87 \\
\hline F $57-0.7$ & $0.001887 \mathrm{~N} / \mathrm{mmI}$ & $1.91302(0.95651)$ & 2676.775 \\
\hline F $57-0.8$ & $0.001898 \mathrm{~N} / \mathrm{mmI}$ & $1.92417(0.962087)$ & 2692.255 \\
\hline F $75-0.7$ & $0.001898 \mathrm{~N} / \mathrm{mmI}$ & $1.92417(0.962087)$ & 2601.285 \\
\hline
\end{tabular}

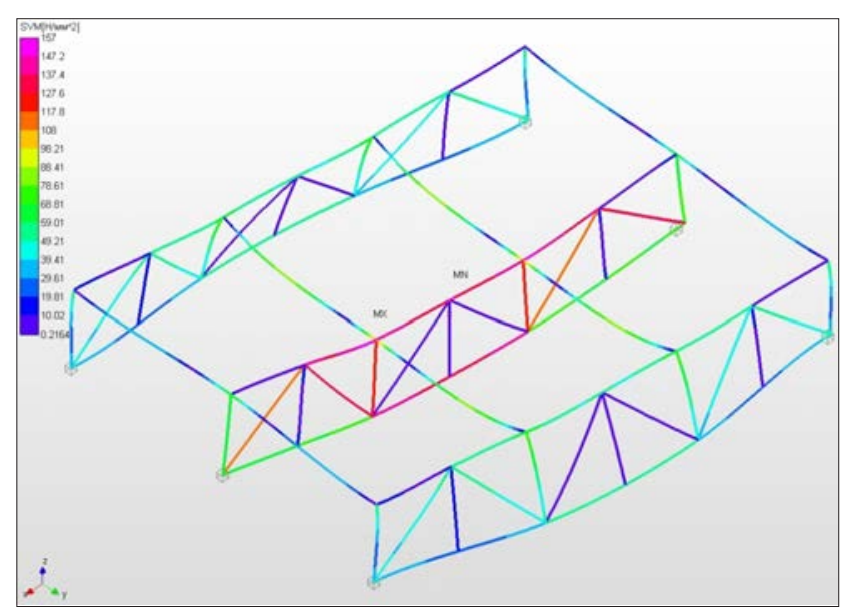

Fig. 3. The Results of carcass calculation's in APM WinMachine (equivalent tension)

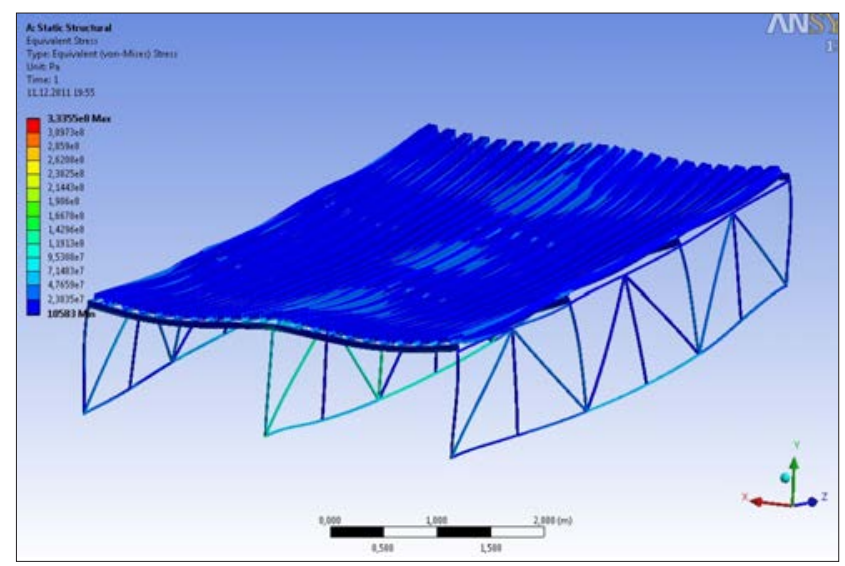

Fig. 5. Calculation of a roof in Workbench (equivalent stress)

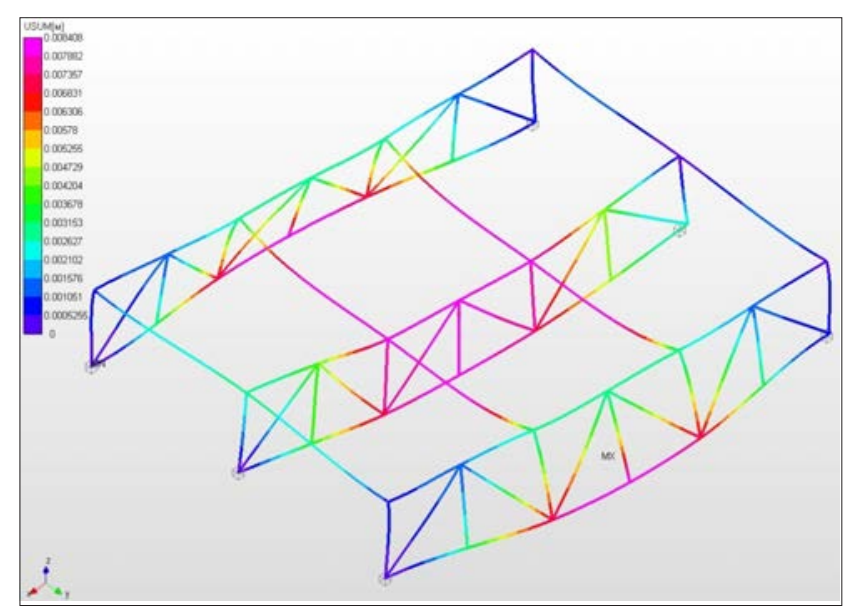

Fig. 4. The Results of carcass calculation's in APM WinMachine (total displacement)

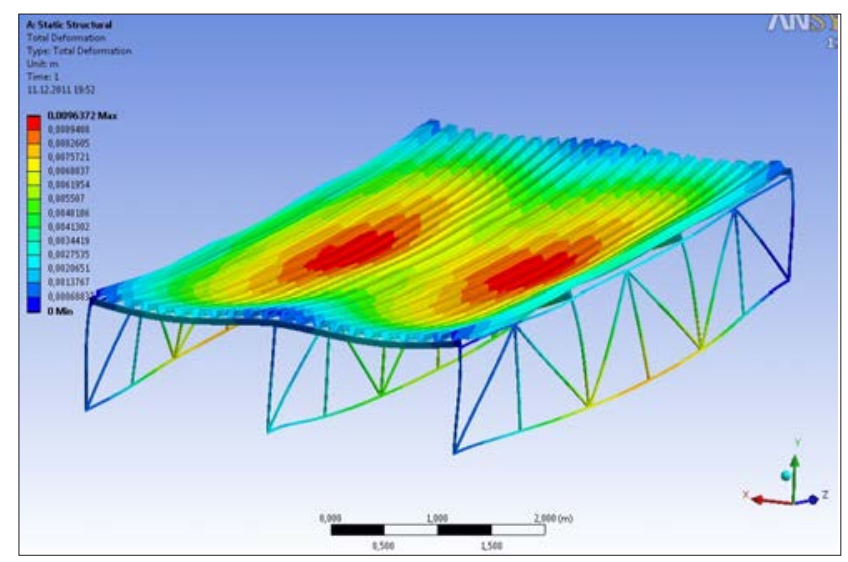

Fig. 6. The roof calculation's in Workbench (displacement) 
Table 2. The calculation results in software packages of APM WinMachine and Workbench

\begin{tabular}{|c|c|c|c|c|c|c|}
\hline \multirow{2}{*}{\begin{tabular}{c}
\multirow{2}{*}{$\begin{array}{c}\text { №1 flooring } \\
\text { thickness }\end{array}$} \\
\cline { 2 - 7 }
\end{tabular}} & \multicolumn{2}{|c|}{$\begin{array}{c}\text { The calculation results } \\
\text { in APM WinMachine }\end{array}$} & \multicolumn{2}{|c|}{$\begin{array}{c}\text { The calculation results } \\
\text { in Workbench }\end{array}$} & \multicolumn{2}{c|}{$\begin{array}{c}\text { The percent of decrease } \\
\text { in the characteristic, \% }\end{array}$} \\
\hline FW35-0.7 & 132 & $\varepsilon$, MM & $\begin{array}{c}\text { The stresses, } \\
\text { MPa }\end{array}$ & $\varepsilon$, мM & The stresses & $\varepsilon$ \\
\hline FW 44-0.7 & 133 & 8.082 & 117.74 & 5.742 & 11.47 & 28.95 \\
\hline F57-0.6 & 132.5 & 8.05 & 117.89 & 5.8 & 11.03 & 27.95 \\
\hline F7-0.7 & 133.3 & 8.1 & 117.61 & 5.75 & 11.77 & 29.01 \\
\hline F57-0.8 & 134 & 8.145 & 117,5 & 5.72 & 12.31 & 29.77 \\
\hline F75-0.7 & 134 & 8.145 & 116.18 & 5.72 & 13.3 & 29.77 \\
\hline
\end{tabular}

$\varepsilon-$ Deformation of the central trusses in the middle of the lower belt

The calculation results by means of these mathematical packages given in table 2 .

At calculation of decrease, percent in the characteristic the data obtained in the environment of APM WinMachine were accepted to $100 \%$.

Conclusion. So, the use of modern mathematical packages: APM WinMachine, SolidWorks, ANSYS allows to consider influence of a profiled leaf rigidity on the overall work of the roof. During the calculation, the following results were obtained:

1. The profiled flooring increases rigidity of a roof, reducing a trusses deflection (by 20-30\%).
2. The profiled flooring changes a picture of stresses distribution in the trusses elements.

3. By taking into account of profiled flooring rigidity there is an opportunity to reduce metal consumption of overlapping designs of industrial buildings

4. Studies need to be conducted for each case of profiled decking (depending on the parameters roof - type of trusses, step of trusses, span values etc.).

5. The calculation of roofing structures should be considering building carcass as a whole rather than the individual trusses.

\section{Bibliography}

1. Болотов М.Г. Аналітичний огляд основних причин та наслідки аварій будівель та споруд, що сталися на території України за останні п’ять років. Вісник ЧНТУ. 2013. №4. С. 197-204.

2. Клименко Ф.Є., Барабаш В.М., Стороженко Л.І. Металеві конструкції. Львів : Світ, 2002. 312 с.

3. Болотов Г.П., Олексієнко С.В., Болотов М.Г. Ручне дугове зварювання будівельних сталей малоамперною дугою модульованим струмом. Технічні науки та технологіï. 2015. № 1 (1). С. 48-53.

4. Гринь И.М. Строительные конструкции из дерева и синтетических материалов: проектирование и расчёт. Киев : Вища шк, 1975. 297 с.

5. Болотов М.Г. Оцінка несучої здатності зварних з'єднань арматури залізобетону / Болотов М.Г., Болотов Г.П., Ганєєв Т.Р., Корзаченко М.М. Вісник ЧНТУ. Серія: Технічні науки та технології. 2017. № 1(7). С. 58-67.

6. Горев В.В., Уваров Б.Ю., Филиппов В.В. и др. Металлические конструкции. Конструкции зданий (том 2). Учебник для строительных вузов. В трех томах. Изд. 2-е. исправ. Москва : Высш. шк., 2002. 528 с.

7. Евдокимцев О.В., Умнова О.В. Проектирование и расчет стальных балочных клеток. Тамбовский государственный технический университет. Тамбов : ТГТУ, 2005. 136 с.

8. Еропов Л.А. Покрытия и кровли гражданских и промышленных зданий. 2-е изд., перераб. и доп. Москва : АСB, 2004. - 247 с.

\section{References}

1. Bolotov M.G. AnalItichniy oglyad osnovnih prichin ta naslIdki avarIy budIvel ta sporud, scho stalisya na teritorIYi UkraYini za ostannI p'yat rokIv.[Analytical review of the main causes and consequences of accidents of buildings and structures that occurred in Ukraine over the last five years ] / VIsnik ChNTU. - 2013. - \#4.- S. 197-204 .

2. Klimenko F.E., Barabash, V.N., Storozhenko L.I. Metalevi konstrukcii. [Metal structures] - 2nd ed., Straighten. add. - Lviv: Svit, 2002. - 312 p.

3. Bolotov G.P., Oleksienko S.V., Bolotov M.G. (2015) Ruchne dugove zvaryuvannya budivelnih staley maloampernoyu dugoyu modulovanim strumom [Hand arc welding builds steels by littleampere arc with modulation of current]. / G. P. Bolotov // Tehnichni nauki ta tehnologiyi, no.1 (1). - pp. 48-53. 
4. Grin' I.M. Stroitel'nye konstrukcii iz dereva i sinteticheskih materialov: proektirovanie i raschyot [Building constructions made of wood and synthetic materials: design and calculation] / I.M. Grin' - Kiev: Vishcha shk, 1975 $297 \mathrm{~s}$.

5. Bolotov M.G. OtsInka nesuchoYi zdatnostI zvarnih z'Ednan armaturi zallzobetonu.[ Assessment of the bearing capacity of welded joints of reinforced concrete reinforcement.] / Bolotov M.G., Bolotov G.P., GanEEv T.R., Korzachenko M.M. // VIsnik ChNTU. SerIya TehnIchnI nauki ta tehnologIYi. \#1(7), 2017. S. 58-67.

6. Gorev V.V., Uvarov B.YU., Filippov V.V. i dr. Metallicheskie konstrukcii. Konstrukcii zdanij (tom 2) Uchebnik dlya stroitel'nyh vuzov. [Metal structures]. V trekh tomah. Izd. 2-e. isprav., M.: Vyssh. shk. , 2002g. -528s.

7. Evdokimcev O.V., Umnova O.V. Proektirovanie i raschet stal'nyh balochnyh kletok. [Design and calculation of steel beam cells.] Tambovskij gosudarstvennyj tekhnicheskij universitet. Tambov: TGTU, 2005g. -136s. Eropov L.A. Pokrytiya i krovli grazhdanskih i promyshlennyh zdanij. [Coatings and roofs of civil and industrial buildings]. 2-e izd., pererab. i dop. - M.: ASV, 2004. - 247 s.

\section{ДОСЛІДЖЕННЯ ВПЛИВУ ГЕОМЕТРИЧНИХ ПАРАМЕТРІВ ПРОФІЛЬОВАНОГО НАСТИЛУ НА НЕСУЧУ ЗДАТНІСТЬ ПОКРІВЛІ}

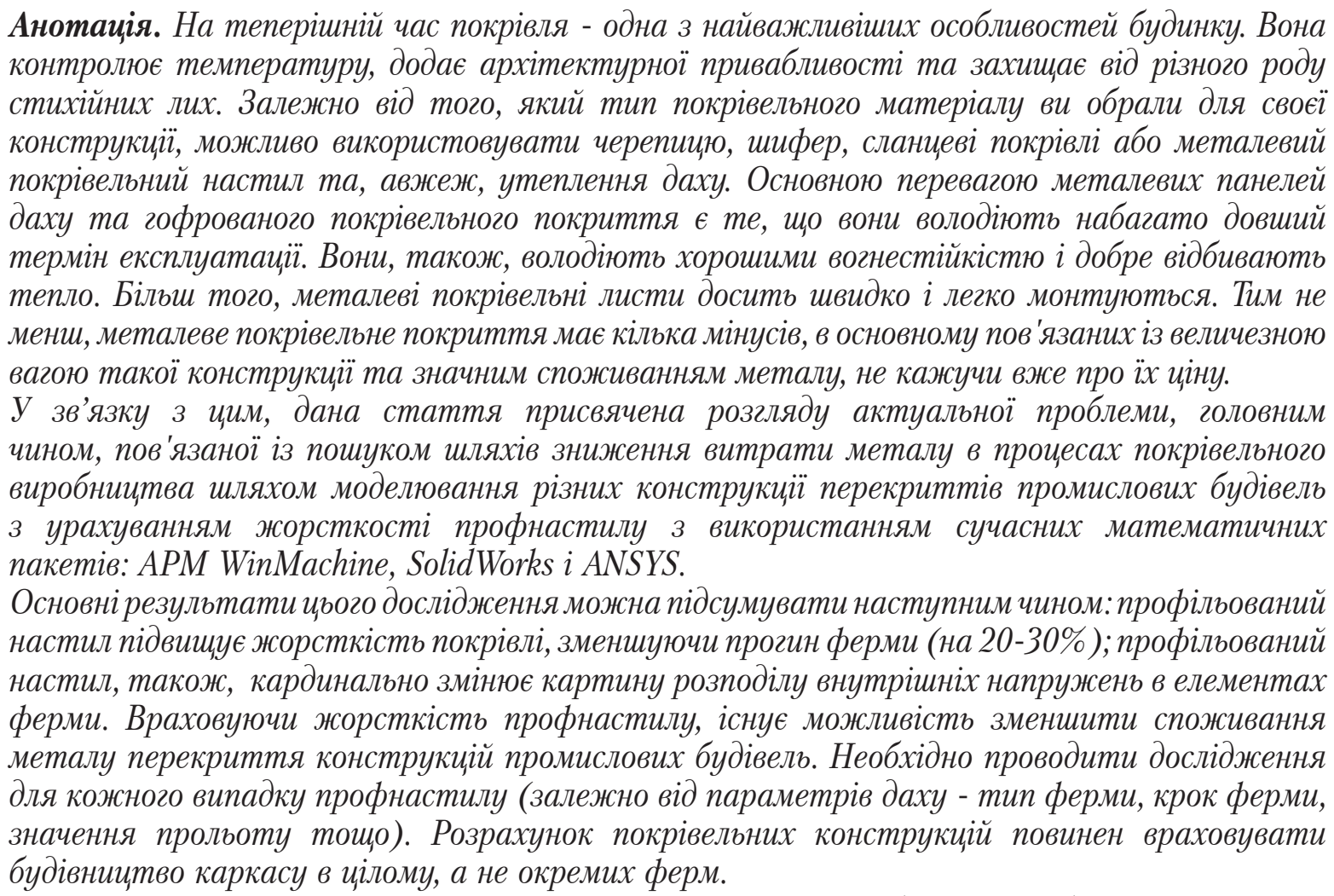

Ключові слова: металоконструкція, перекриття, профнастил, ферма, витрата металу.

\section{Прибитько I.O.}

к.т.н., доцент кафедри технологій зварювання і будівництва, Національний університет «Чернігівська політехніка», м. Чернігів Болотов М.Г.

к.т.н., доцент кафедри технологій зварювання і будівництва, Національний університет «Чернігівська політехніка», м. Чернігів Руденко М.М.

старший викладач кафедри технологій зварювання і будівництва, Національний університет «Чернігівська політехніка», м. Чернігів 